DIDAKTIKA

Jurnal Pendidikan Sekolah Dasar

Volume 1, Nomor 1, 15-22, 2019

Journal homepage: https://journal.uny.ac.id/index.php/didaktika

Implementation of POE (Predict, Observe, Explain) Learning Model by Integrating Technology in Constructing Technological Literacy for Prospective Teachers of Elementary School Teachers

\author{
Deni Moh. Budiman 1, , \\ 1STKIP Sebelas April Sumedang, Indonesia
}

\begin{abstract}
This research was conducted to test the effectiveness of the application of the learning model of POE (Predict, Observe, Explain) by integrating technology in constructing technological literacy of elementary school science teacher candidates. The study was conducted by comparing learning using the POE model by integrating technology in the experimental class with without integrating technology in the control class. The research method used was a quasi-experimental research design with The Randomized Pretest - Posttest Control Group Design. The sample of this research is the students of elementary science teacher candidates selected by cluster random sampling. The research instrument used in the form of a test device to measure technological literacy with a reliability index of 0.94 . The results showed that significantly learning using the POE model by integrating technology was more effective in increasing technological literacy compared to learning without integrating technology.
\end{abstract}

Keywords: POE Learning Model, Technological Literacy.

\title{
Implementasi Model Pembelajaran POE (Predict, Observe, Explain) dengan Mengintegrasi Teknologi dalam Mengkonstruk Technological Literacy Mahasiswa Calon Guru IPA Sekolah Dasar
}

\begin{abstract}
Abstrak
Penelitian ini dilaksanakan untuk menguji efektivitas penerapan model pembelajaran POE (Predict, Observe, Explain) dengan mengintegrasi teknologi dalam mengkonstruk technological literacy mahasiswa calon guru IPA Sekolah Dasar. Penelitian dilakukan dengan membandingkan antara pembelajaran menggunakan model POE dengan mengintegrasi teknologi pada kelas eksperimen dengan tanpa mengintegrasi teknologi pada kelas kontrol. Metode penelitian yang digunakan adalah kuasi eksperimen dengan desain penelitian The Randomized Pretest - Posttest Control Group Design. Sampel penelitian adalah mahasiswa calon guru IPA SD yang dipilih secara cluster random sampling. Instrumen penelitian yang digunakan berupa perangkat tes untuk mengukur technological literacy dengan indeks reliabilitas sebesar 0,94. Hasil penelitian menunjukkan bahwa secara signifikan pembelajaran menggunakan model POE dengan mengintegrasi teknologi lebih efektif dalam meningkatkan technological literacy dibandingkan dengan pembelajaran tanpa mengintegrasi teknologi.
\end{abstract}

Kata kunci: Model Pembelajaran POE, Technological Literacy.

\footnotetext{
${ }^{\square}$ Corresponding Author:

Affiliation Address: Jl. Angkrek No.19, Situ, Kec. Sumedang Utara, Kabupaten Sumedang, Jawa Barat 45323

E-mail: denimohbudiman@gmail.com
} 


\section{PENDAHULUAN}

Pendidikan merupakan usaha bimbingan yang dilakukan secara sadar dan diberikan kepada individu dalam masa tumbuh kembangnya untuk mendewasakan karakter individu dengan tujuan untuk menambah ilmu pengetahuan, membentuk karakter diri, dan mengarahkan anak untuk menjadi pribadi yang lebih baik. Dengan kata lain, pendidikan juga merupakan bagian untuk menjadikan manusia seutuhnya. Wahyudin, dkk. (2008) mengungkapkan bahwa, "Pendidikan adalah humanisasi, yaitu upaya untuk memanusiakan manusia atau upaya untuk membantu manusia agar mampu mewujudkan diri sesuai dengan martabat kemanusiaannya".

Tanpa pendidikan akan sulit diperoleh hasil dari kualitas sumber daya manusia yang maksimal. Di zaman sekarang ini, masalah pendidikan menjadi hal yang penting terutama bagi bangsa Indonesia guna meningkatkan kualitas sumber daya manusia agar mampu bersaing di tingkat global. Salah satu upaya untuk meningkatkan kualitas sumber daya manusia adalah dengan cara memperbaiki mutu pendidikan. Pendidikan merupakan suatu dasar pembangunan karakter, mental dan spiritual manusia sehingga dapat dijadikan sebagai tolok ukur kualitas suatu bangsa. Perbaikan mutu pendidikan di Indonesia telah dilakukan dengan berbagai cara salah satunya melalui peningkatan kualitas proses belajar mengajar di sekolah dasar.

Sekolah dasar sebagai jenjang pendidikan paling dasar merupakan sarana pembentukan karakter dan pengetahuan awal siswa. Keberhasilan pendidikan di sekolah dasar ini akan menjadi pondasi awal bagi siswa untuk mengembangkan kecerdasan, keterampilan dan menunjang kualitas belajar siswa pada jenjang pendidikan selanjutnya. Dengan demikian, pendidikan dasar merupakan sesuatu yang penting dalam menunjang kualitas sumber daya manusia Indonesia. Keberhasilan pembelajaran sebagai proses pendidikan di sekolah dipengaruhi oleh banyak faktor diantaranya adalah guru, siswa, sarana dan prasarana, kurikulum, lingkungan sosial, dan lain-lain. Namun dari faktor-faktor tersebut, guru merupakan faktor terpenting.

Salah satu mata pelajaran di tingkat Sekolah Dasar adalah Ilmu Pengetahuan Alam. Pembelajaran IPA sangat berperan dalam proses pendidikan dan juga perkembangan teknologi, karena tujuan pembelajaran IPA adalah sebagai sarana bagi siswa untuk mengembangkan ilmu pengetahuan dan teknologi sehingga pemahaman tentang alam dan hasil penemuan siswa dapat dikembangkan dan diterapkan dalam kehidupan sehari-hari. Hal ini sejalan dengan prinsip kegiatan pembelajaran yang dilaksanakan di perguruan tinggi yang berpusat pada mahasiswa dan memberikan kesempatan pada mahasiswa untuk mengembangkan potensinya (UU Pendidikan Tinggi, 2012). Kegiatan pembelajaran di perguruan tinggi yang berstatus Lembaga Pendidikan Tenaga Kependidikan (LPTK) tidak hanya memberikan pemahaman mahasiswa terhadap bahan ajar saja tetapi harus mempertimbangkan standar kompetensi yang dimiliki peserta didik yang akan mereka didik sesuai dengan jenjang pendidikannya.

Pada jenjang pendidikan SD, pembelajaran IPA haruslah mengarah pada tujuan yang tertuang pada kurikulum KTSP (Depdiknas, 2006) salah satunya yakni dapat mengembangkan rasa ingin tahu, sikap positif dan kesadaran tentang adanya hubungan yang saling mempengaruhi antara IPA, lingkungan, teknologi dan masyarakat. Berdasarkan tujuan tersebut dapat dirangkum beberapa kompetensi yang harus dimiliki oleh siswa, salah satunya adalah siswa harus melek terhadap teknologi.

Sementara itu, seiring arus globalisasi yang semakin menguat, peranan teknologi menjadi sangat penting dalam kehidupan sehari-hari. Hal ini ditandai dengan intensitas keterlibatan teknologi dalam kehidupan manusia yang semakin tinggi. Untuk menghadapi globalisasi tersebut, diperlukan pribadi-pribadi berkualitas yang memiliki kehandalan dan daya saing tinggi serta menguasai teknologi, sehingga mampu menghadapi tantangan dan dapat menyelesaikan permasalahan yang ada. Oleh karena itu, sudah sepatutnya pembelajaran IPA dapat mengembangkan kemampuan lainnya yang tidak hanya berorientasi pada konsep saja. Salah satunya yaitu bagaimana siswa dapat mengaplikasikan atau menerapkan konsep tersebut dalam bentuk nyata yang diwujudkan dalam produk teknologi. Untuk alasan itu, "virus" 
technological literacy harus didengungkan sedini mungkin agar kita dapat menjadi pelaku dari perkembangan teknologi dan bukan menjadi obyek dari perkembangan tersebut.

Pentingnya siswa Sekolah Dasar melek terhadap teknologi ini akan memberikan dampak pada usaha LPTK malalui kegiatan perkuliahan dalam membekali mahasiswa calon guru IPA SD dengan sejumlah kompetensi yang mumpuni, salah satunya adalah technological literacy. Sehingga pada masa pengabdiannya, guru IPA SD mampu melatihkan kompetensi tersebut kepada peserta didiknya. Bagaimana mungkin seorang pendidik bisa mengembangkan kompetensi peserta didiknya apabila pendidiknya sendiri tidak menguasai kompetensi yang akan dilatihkan.

Mengingat pentingnya technological literacy bagi calon guru IPA SD maka kegiatan pembelajaran IPA di LPTK harus menggunakan model pembelajaran yang efektif dalam melatih dan mengembangkan kompetensi tersebut.

Namun, Blazely, Lloyd D., et.al, (1997) melaporkan hasil penelitiannya bahwa pembelajaran cenderung sangat teoritik dan tidak terkait dengan lingkungan di mana anak berada. Akibatnya mahasiswa tidak mampu mengaplikasikan apa yang dipelajarinya untuk memecahkan masalah kehidupannya seharihari. Senada dengan penyataan tersebut, Ferrer (dalam Chandra, 2010) menyimpulkan hasil studinya bahwa pelajaran sains di Negara berkembang di Asia tidak dilengkapi dengan pengetahuan dan kemampuan yang membuat mereka mampu memecahkan masalah kehidupan sehari-hari untuk memperbaiki kualitas kehidupannya meskipun pembelajaran tentang teknologi sudah diberikan ketika mereka memasuki sekolah menengah dan mahasiswa tidak mampu memecahkan masalah, lemah dalam proses penemuan, tidak dapat mengembangkan inovasi serta tidak dapat mentransfer teknologi.

Dari permasalahan di atas, perlu dilakukan perubahan dalam pola pembelajaran sains di level perguruan tinggi, dimana di dalamnya melibatkan teknologi baik sebagai tools maupun sebagai knowledge atau product knowledge. Hal ini dimaksudkan agar pembelajaran sains tidak hanya berorientasi kepada pemahaman konsep saja, tetapi juga memberikan wahana berkembangnya keterampilan berfikir mahasiswa berkenaan dengan penerapan sains dalam kehidupan sehari-hari yang diwujudkan dalam bentuk produk teknologi, sehingga diharapkan technological literacy mahasiswa pun ikut berkembang.

Salah satu solusi dari permasalahan di atas yakni dengan menerapkan pembelajaran yang bervariasi dan menekankan pengetahuan yang diperoleh mahasiswa merupakan hasil pengalaman belajarnya sendiri serta mengintegrasikan teknologi di dalamnya. Pada tahun 1968 The European Council (Dewan Eropa) telah menyimpulkan bahwa suatu pendidikan umum yang baik harus mencakup orientasi kearah teknologi mutakhir. Pembelajaran yang demikian dapat tercermin pada pembelajaran sains menggunakan model POE dengan mengintegrasi teknologi. Oleh karena itu peneliti tertarik untuk mengkaji penerapan model pembelajaran POE (Predict, Observe, Explian) dengan mengintegrasi teknologi dalam mengkonstruk technological literacy mahasiswa calon guru IPA Sekolah Dasar.

\section{METODE}

Jenis penelitian yang dilakukan adalah penelitian kuantitatif dengan metode kuasi eksperimen dengan desain penelitian The Randomized Pretest-Posttest Control Group Design (Fraenkel, 1993). Adapun skema The Randomized Pretest - Posttest Control Group Design seperti pada tabel berikut ini.

Tabel 1. Skema Randomized Control Group Pretest Posttest Design

\begin{tabular}{llcl}
\hline Kelompok & $\begin{array}{c}\text { Pre- } \\
\text { test }\end{array}$ & Treatment & $\begin{array}{l}\text { Post- } \\
\text { test }\end{array}$ \\
\hline Eksperimen & 01 & $\mathrm{Xa}$ & $\mathrm{O} 2$ \\
\hline Pembanding & 01 & $\mathrm{Xb}$ & $\mathrm{O} 2$ \\
\hline
\end{tabular}

Populasi dalam penelitian ini adalah seluruh mahasiswa PGSD semester 2, sedangkan yang menjadi sampel dalam penelitian ini adalah dua kelas dari keseluruhan populasi yang dipilih secara cluster random sampling.

Instrumen penelitian yang digunakan berupa perangkat tes untuk mengukur technological literacy dengan indeks reliabilitas sebesar 0,94. 
Efektivitas pembelajaran baik menggunakan model POE dengan mengintegrasi teknologi maupun tanpa mengintegrasi teknologi dalam meningkatkan technological literacy mahasiswa dicari dengan menghitung rata-rata gain ternormalisasi berdasarkan kriteria efektivitas pembelajaran menurut Hake (1997). Rumus yang digunakan untuk menghitung gain ternormalisasi adalah:

$$
\langle g\rangle=\frac{\text { skor tes akhir }- \text { skor tes awal }}{\text { skor maksimum - skor tes awal }}
$$

\section{HASIL DAN PEMBAHASAN}

Efektivitas penerapan model pembelajaran POE dalam meningkatkan technological literacy mahasiswa calon guru IPA Sekolah Dasar, dilakukan dengan mengolah data hasil pre-test dan post-test sehingga diperoleh gain ternormalisasi untuk masing-masing kelas.

Dari hasil pengolahan data, perbandingan rata-rata skor gain ternormalisasi dari kedua kelas ditunjukan pada Tabel 2 berikut.

Tabel 2. Perbandingan Rata-rata Gain Ternormalisasi Technological Literacy

\begin{tabular}{lll}
\hline Kelas & $\begin{array}{l}\text { Rata-rata } \\
\text { gain ternormalisasi }\end{array}$ & Kategori \\
\hline Eksperimen & 0.53 & Sedang \\
\hline Kontrol & 0.29 & Rendah \\
\hline
\end{tabular}

Merujuk Tabel 2 di atas, diagram batang rata-rata gain ternormalisasi pemahaman konsep dapat ditunjukkan melalui gambar berikut:

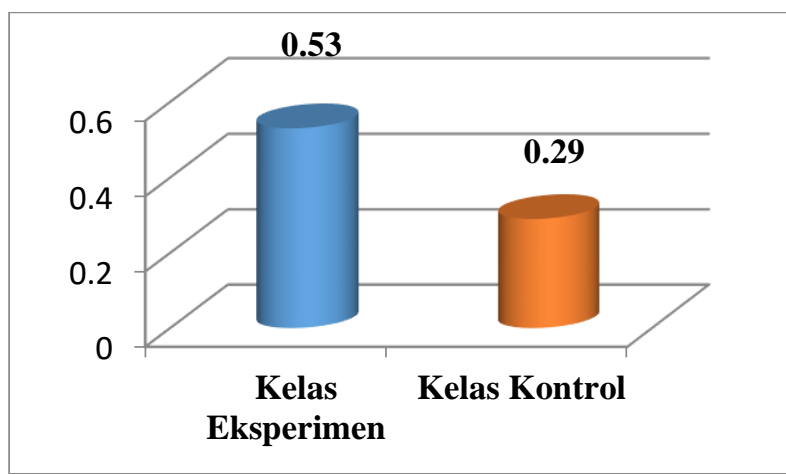

Gambar 1. Diagram Batang Rata-rata Gain Ternormalisasi Technological Literacy

Berdasarkan gambar di atas, terlihat bahwa nilai rata-rata gain ternormalisasi technological literacy pada kelas eksperimen yang menggunakan model pembelajaran POE dengan mengintegrasi teknologi lebih besar dibandingkan dengan nilai rata-rata gain ternormalisasi technological literacy pada kelas kontrol yang tanpa mengintegrasi teknologi. Artinya adalah bahwa pembelajaran menggunakan model pembelajaran POE dengan mengintegrasi teknologi lebih efektif dalam meningkatkan technological literacy mahasiswa dibandingkan dengan tanpa mengintegrasi POE. Hal ini sesuai dengan yang diungkapkan Mergendoller (2005) bahwa jika hasil rata-rata gain ternormalisasi dari suatu pembelajaran lebih tinggi dari hasil rata-rata gain ternormalisasi dari pembelajaran lainnya, maka dikatakan bahwa pembelajaran tersebut lebih efektif dalam meningkatkan suatu kompetensi dibandingkan pembelajaran lain.

Perbedaan hasil ini disebabkan oleh beberapa faktor diantaranya, pada pembelajaran menggunakan model pembelajaran POE dengan mengintegrasi teknologi, selain mendapatkan konsep IPA mahasiswa dilatih untuk menggunakan, menilai, mengelola dan memahami teknologi. Bandingkan dengan pembelajaran tanpa mengintegrasi teknologi, teknologi hanya disinggung sebagai aplikasi konsep yang dipelajari tanpa lebih lanjut memahaminya.

Dengan demikian, mahasiswa diajak untuk memahami konsep melalui pengalaman konkret dengan mempelajari prinsip, teori, dan hukum sains yang menjadi prinsip kerja dari berbagai produk teknologi. Hal ini sesuai dengan penemuan pada studi yang dilakukan oleh Aikenkord, Fleming dan Ryan (1987) tentang VOSTS (Views an Science Technology and Society) dalam (Chandra, 2010) menemukan bahwa sebagian besar siswa merefrensikan teknologi dalam sains. Seperti dinyatakan sebelumnya bahwa technological literacy adalah suatu keadaan dimana mahasiswa aktif terlibat dalam proses teknologi atau belajar memanfaatkan hasil teknologi tidak hanya mengetahui atau mengenal saja, namun juga mampu memanfaatkan teknologi sebaik mungkin.

Tahapan model pembelajaran POE dengan mengintegrasi teknologi dapat memfasilitasi mahasiswa untuk dapat mengembangkan pengetahuannya sendiri dengan cara mencari informasi melalui buku, 
majalah dan internet. Sehingga peran mahasiswa tidak hanya sebagai objek transfer informasi dari seorang dosen saja. Lebih dari pada itu, memberikan peluang kepada mahasiswa untuk bisa membangun pengetahuannya sendiri. Hal ini sesuai dengan pandangan konstruktivisme yakni menekankan pengetahuan yang diperoleh peserta didik merupakan hasil pengalaman belajarnya sendiri.

Integrasi teknologi dalam model pembelajaran POE secara umum menitikberatkan pada aplikasi konsep berupa produk teknologi yang biasa digunakan sehari-hari. Adapun pembelajarannya dimulai dengan tahap predict dimana mahasiswa diajak untuk mengamati mengenai prinsip kerja dongkrak hidraulik dengan segala atribut yang ada pada produk teknologi tersebut. Dengan hasil pengamatan yang dilakukan, mahasiswa membuat suatu prediksi apa yang terjadi dan hasil apa yang diperoleh ketika menggunakan dongkrak hidraulik tersebut. Tahap kedua adalah observe dimana mahasiswa melakukan kegiatan eksperimen dengan alat dan bahan yang telah tersedia. Eksperimen dilakukan untuk membuktikan apakah prediksi yang telah dibuat oleh mahasiswa benar atau salah terkait dengan prinsip kerja dongkrak hidraulik. Kemudian pada tahap ketiga yakni explain, mahasiswa mencari informasi yang dibutuhkan untuk menyelesaikan tugas yang ada pada buku kerja siswa, baik melalui buku, majalah ataupun internet dengan pengawasan guru untuk menjelaskan secara rinci mengenai prinsip kerja dongkrak hidraulik. Selain itu, dosen menjelaskan kepada mahasiswa mengenai materi yang dipelajari sebagai pemantapan konsep.

Tahapan-tahapan tersebut menuntut perkembangan pemikiran mahasiswa yang kemudian diarahkan oleh dosen dalam kegiatan diskusi tiap kelompok untuk mendapatkan konsep, prinsip, teori dan hukum sains secara utuh dari prinsip kerja berbagai produk teknologi. Berbeda halnya dengan kelas kontrol, dimana mahasiswa melakukan kegiatan praktikum untuk menemukan konsep, prinsip dan hukum sains. Namun konsep, prinsip dan hukum sains tersebut kurang mendapatkan porsi untuk menerapkannya dalam kehidupan sehari-hari, sehingga kebermaknaan dari pembelajaran itu sendiri dirasa kurang.

Ada empat indikator technological literacy mahasiswa, yakni menggunakan, menilai, mengelola dan memahami. Untuk menganalisis peningkatan tiap indikator technological literacy mahasiswa caranya adalah dengan terlebih dahulu mengelompokkan data gain ternormalisasi berdasarkan indikator technological literacy mahasiswa. Nilai rata-rata gain ternormalisasi berdasarkan indikator technological literacy mahasiswa untuk kelas eksperimen dan kelas kontrol ditunjukan oleh Tabel 3 berikut.

Tabel 3. Nilai Rata-rata Gain Ternormalisasi Tiap Indikator Technological Literacy

\begin{tabular}{|c|c|c|c|c|c|}
\hline \multirow{2}{*}{$\begin{array}{l}\text { Indikator } \\
\text { Technological } \\
\text { Literacy }\end{array}$} & \multicolumn{2}{|l|}{$\langle g\rangle$} & \multicolumn{2}{|c|}{ Kategori } & \multirow[t]{2}{*}{ Ket } \\
\hline & $E$ & K & $E$ & $\mathrm{~K}$ & \\
\hline Menggunakan & 0.63 & 0.26 & $S$ & $\mathrm{R}$ & - \\
\hline Menilai & 0.44 & 0.41 & $S$ & $S$ & Uji-t \\
\hline Mengelola & 0.34 & 0.18 & $S$ & $\mathrm{R}$ & - \\
\hline Memahami & 0.43 & 0.22 & $S$ & $\mathrm{R}$ & - \\
\hline
\end{tabular}

Perbandingan angka rata-rata gain ternormalisasi kemampuan menggunakan, menilai, mengelola dan memahami untuk kelas eksperimen menunjukkan bahwa ratarata gain ternormalisasi paling besar adalah pada kemampuan menggunakan dan rata-rata gain ternormalisasi paling kecil adalah pada kemampuan mengelola. Sedangkan untuk kelas kontrol menunjukkan bahwa rata-rata gain ternormalisasi paling besar adalah pada kemampuan menilai dan rata-rata gain ternormalisasi paling kecil adalah pada kemampuan mengelola.

Untuk mengetahui signifikansi perbedaan nilai rata-rata gain ternormalisasi antara kelas eksperimen dan kelas kontrol pada indikator technological literacy yang memiliki kategori yang sama, diperoleh melalui pengolahan statistik. Namun sebelumnya dilakukan uji normalitas dan uji homogenitas terlebih dahulu.

Uji normalitas distribusi data kemampuan menilai pada kelas eksperimen dan kelas kontrol dilakukan dengan OneSample Kolmogorov-Smirnov Test dengan menggunakan bantuan Software Statistical Package for Social Science (SPSSTM) versi 17.0 for window. Diperoleh nilai signifikansi dari 
dua kelas yang ditunjukkan pada Tabel 4 berikut.

Tabel 4. Uji Normalitas Data Tiap Indikator Technological Literacy

\begin{tabular}{llllll}
\hline Ind. & Kelas & \multicolumn{2}{l}{ Kolmogorov-Smirnov } & Ket \\
\cline { 3 - 5 } & & Statistik & $\mathrm{df}$ & $\mathrm{Sig}$ & \\
\hline Menilai & $\mathrm{E}$ & 0.177 & 25 & 0.041 & Tdk \\
& & & & & Normal \\
\cline { 2 - 5 } & $\mathrm{K}$ & 0.187 & 25 & 0.024 & $\begin{array}{l}\text { Tdk } \\
\end{array}$ \\
& & & & Normal
\end{tabular}

${ }^{*}$ sig : signifikansi $\alpha=0.05$ (2 tailed)

Karena indikator menilai tidak berdistribusi normal, maka untuk mengetahui perbedaan peningkatan indikator menilai antara kelas eksperimen dan kelas kontrol digunakan uji Mann-Whitney U, dan diperoleh hasilnya seperti pada Tabel 5 berikut :

Tabel 5. Uji Mann-Whitney U untuk Tiap Indikator Technological Literacy

\begin{tabular}{lllll}
\hline Indikator & Data & Statistik & Sig $^{*}$ & Ket. \\
\hline Menilai & Mean & 301.000 & 0.819 & Tidak \\
& & & & Terdapat \\
& & & & Perbedaan
\end{tabular}

${ }^{*}$ sig : signifikansi $\alpha=0.05$ (2 tailed)

Berdasarkan pengolahan data di atas, diperoleh hasil bahwa pembelajaran menggunakan model pembelajaran POE dengan mengintegrasi teknologi lebih efektif dalam meningkatkan technological literacy mahasiswa calon guru IPA Sekolah Dasar khususnya untuk indikator menggunakan, mengelola dan memahami dibandingkan dengan tanpa mengintegrasi teknologi. Sedangkan peningkatan untuk indikator menilai baik pada pembelajaran menggunakan model POE dengan mengintegrasi teknologi maupun tanpa mengintegrasi teknologi tidak ada perbedaan yang signifikan.

Model pembelajaran POE adalah model pembelajaran yang menganut teori konstruktivisme dan melibatkan siswa untuk berpikir kritis dalam memahami materi yang akan dipelajari. Joyce dan Weil maupun Arend menggolongkan POE sebagai model pembelajaran karena melihat sintaksnya yang ketat (Warsono dan Haryanto, 2016). Model pembelajaran POE dengan mengintegrasi teknologi merupakan pembelajaran yang setiap langkah kegiatannya melibatkan teknologi baik sebagai media maupun sebagai pengetahuan.

Adapun penjelasan mengenai langkahlangkah model POE dengan mengintegrasi teknologi ini dijelaskan secara rinci sebagai berikut.

Predict, memulai pembelajaran dengan menghadapkan para pembelajar dengan seperangkat alat dan bahan percobaan, serta produk teknologi yang terkait dengan materi yang akan disampaikan. Kemudian dosen menjelaskan apa saja yang harus dilakukan mahasiswa terkait peralatan tersebut. Para mahasiswa kemudian membuat suatu prediksi apa yang dapat terjadi, hasil apa yang bakal diperoleh dengan bereksperimen menggunakan alat dan bahan serta produk teknologi tersebut. Selanjutnya mereka mencoba membuat sebuah penjelasan awal (eksplanasi) yang menurut mereka merupakan hasil yang benar. Mereka mengumpulkan dan mendaftar sejumlah eksplanasi, selanjutnya melakukan pemilihan suara secara bebas dan tertutup untuk menetapkan eksplanasi mana yang paling baik dan harus dibuktikan kebenarannya melalui pengamatan dalam percobaan.

Observe, yaitu dilakukan demonstrasi atau percobaan dengan menggunakan produk teknologi yang telah disiapkan kemudian diamati. Dari sini dapat diketahui eksplanasi mana yang paling benar dan prediksi eksplanasi mana saja yang ternyata salah. Dapat saja terjadi beberapa prediksi eksplanasi yang ternyata benar, sebaliknya dapat juga terjadi bahwa seluruh prediksi eksplanasi yang dibuat sebelumnya ternyata keliru seluruhnya. Tidak masalah, yang paling penting adalah pemberian kesempatan kepada seluruh mahasiswa untuk mengalami sendiri segala sesuatu dan memperoleh hikmah pembelajarannya sendiri.

Explain, kelas sebagai kelompok mencoba melakukan dekonstruksi hasil demonstrasi dan menjelaskan mengapa hal yang didemonstrasikan tersebut terjadi.

Technological Literacy adalah suatu keadaan dimana siswa aktif terlibat dalam proses teknologi atau belajar memanfaatkan hasil teknologi tidak hanya mengetahui atau mengenal saja, namun juga mampu memanfaatkan teknologi sebaik mungkin. Dalam Standards for Technological Literacy 
(ITEA, 2000) menyebutkan bahwa Technological Literacy adalah kemampuan dalam menggunakan, mengelola, menilai dan memahami teknologi.

\section{PENUTUP}

Berdasarkan pengolahan dan analisis data hasil penelitian yang telah dilakukan diperoleh simpulan bahwa integrasi teknologi pada model pembelajaran POE secara signifikan dapat lebih efektif dalam meningkatkan technological literacy mahasiswa dibandingkan dengan model pembelajaran POE tanpa mengintegrasi teknologi. Selain itu, peningkatan tiap indikator technological literacy mahasiswa yang mendapatkan pembelajaran menggunakan model POE dengan mengintegrasi teknologi lebih tinggi dibandingkan dengan mahasiswa yang mendapatkan pembelajaran tanpa mengintegrasi teknologi.

Dari keseluruhan kegiatan penelitian yang telah dilakukan, dapat diajukan beberapa saran untuk penelitian lebih lanjut, antara lain instrumen technological literacy perlu dikembangkan kembali sehingga dihasilkan tes standar technological literacy. Selain itu, diharapkan produk-produk teknologi baik yang dijadikan sebagai tools maupun sebagai knowledge atau product knowledge agar lebih bervarisi lagi untuk penelitian selanjutnya.

\section{DAFTAR PUSTAKA}

Blazely, L. D. et. al. (1997). Science Study. Jakarta: The Japan Grant Foundation.

Chandra, D. T. (2010). Kajian Efektivitas Pembelajaran Fisika Melalui Pendidikan Teknologi Dasar (PTD) di Sekolah Menengah Pertama (SMP). Makalah Pendidikan Fisika UPI: tidak diterbitkan.

Depdiknas. (2006). Kurikulum Tingkat Satuan Pendidikan Sekolah Menengah Pertama. Jakarta: Depdiknas.

Fraenkel, J. R., \& Wallen, N. E. (1993). How to Design and Evaluate Research in Education (second ed.). New York: GrawHill Book Co

Hake, R. R. (1998). Interactive Engagement Methods In Introductory Mechanics
Courses. Tersedia : http://www.physics.indiana.edu/ sdi/I EM-2b.pdf. Accessed on [24 November 2012]

ITEA. (2000). Standards for Technological Literacy: Content for the Study of Technology. Technological for All Americans Project.

Mergendoller, J. R., \& Thomas, J. W. (2000). Managing Project Based Learning : Principles from The Field. Novato, CA : Buck Institute for Education.

Undang-undang Republik Indonesa Nomor 12 tahun 2012 tentang Pendidikan Tinggi.

Wahyudin, dkk. (2008). Pengantar Pendidikan. Jakarta: Universitas Terbuka

Warsono. \& Haryanto. (2016). Pembelajaran Aktif: Teori dan Asesmen. Bandung: PT.Remaja Rosdakarya. 
This page is intentionally left blank 